\title{
PROPUESTA METODOLÓGICA PARA EL ANÁLISIS DEL DOCUMENTAL DE RECONSTITUCIÓN HISTÓRICA: "ALLENDE, LA CAÍDA DE UN PRESIDENTE" DE PABLO GARCÍA
}

\author{
METODOLOGIC PROPOSAL FOR THE ANALYSIS OF HISTORIC \\ RECONSTRUCTION DOCUMENTARY: “ALLENDE, THE \\ PRESIDENT'S FALL” BY PABLO GARCIA
}

MaX Herrera Sepúlveda

RESUMEN

Se analiza un documental que puede ser clasificado como cine de la memoria o cine de autor, que a su vez está montado basándose en otras piezas documentales que se inscriben en un estilo, una línea ideológica y un contexto determinado cual es el cine social y militante de fa década de los setenta. Subjetividad y persuasión, son elementos bàsicos que, a partir de diversos recursos técnicos, el realizador traspasa al espectador desde un componente emotivo en las secuencias y en la narración que acompaña las imágenes. Es una cinta de divulgación histórica.

Palabras clave: Análisis cinematografico, Historia y Memora, Salvador Allende, Chile

\section{ABSTRACT}

It's analyzed a documentary which can be clasified as cinema of the memory or author's cinems, which is based on other documentary pieces which are inscribed in one style, an ideological line and a determinated context such as social cinema on sixties decade. Subjetivity and persuasion are basic elements that, from some technic sources, director give to the public from an emotive conponeat on secuencies and narration which accompany images. It's a movic of historical divulgation.

Keywords: Cinematographic analysis, History and Memory, Salvador Allende, Chili

\section{ACERCA DE LAS IMÁGENES Y SU VALOR DOCUMENTAL}

La imagen junto con la lectura y la oralidad representan unas formas distintas de comunicación que implican el desarrollo de competencias diferentes y formas de construcción del conocimiento heterogéneas. Las competencias comunicativas desarrolladas a partir de la imagen han adquirido especial relevancia en el mundo contemporáneo desde la aparición de la fotografia, medio a través del cual se captura la instantaneidad de una situación, sobre todo cuando este registro implica la conservación de un hecho social. Así lo advierte Burke "En los próximos años será interesante comprobar cómo unos historiadores de una generación que se ha visto expuesta a los ordenadores y a la televisión prácticamente desde su nacimiento y que siempre ha vivido en un mundo saturado de imágenes se sitúa ante los testimonios visuales del pasado"I.

La relación de la cultura con las imágenes retorna, como afirma Machado, cíclicamente a un brote de iconoclasia ${ }^{2}$, que se manifiesta bajo la forma de un horror a las imágenes, de la denuncia de su acción en perjuicio de los hombres y de la destrucción pública de todas sus manifestaciones materiales.

En la cultura cristiano-occidental se ha instalado el dogma de la prohibición de las imágenes. El Antiguo Testamento está repleto de pasajes en los que se penaliza la adoración a las imágenes considerándola

Burke, Peter, 2001. Visto y no visto. El uso de la imagen como docamento kistórico, Barcelona, Editorial Critica, p-16.

I Del griego eikon, imagen, y klasmos, acción de nomper. Machado, Arlindo. 2002. "El cuarto iconoclasmo", Diälogos de la Comurnicaction, Revista Latinoamericana de Facultades de Comanicación Sacial, No 64, p. 54. 
idolatria. Esta prohibición biblica aún es respetada por las corrientes más ortodoxas del judaismo. El rechazo a cualquier objeto iconográfico representa el apego a la ley de Moisés.

Estos ciclos iconoclastas vienen a confirmar el poder de la palabra escrita sobre la imagen, una especie de "literolatria" o el culto del libro y de las letras. Con la revolución cultural que comportó la aparición de la imprenta como medio eficaz de difusión de las ideas perdió acaso la imagen su carácter significante quedando relegada a un ámbito oculto: "No por azar, la historia de las imágenes estuvo casi siempre asociada (excepto en sus breves interregnos de liberación) a las actividades marginales o clandestinas (muchas veces prohibidas), al contexto underground, a la practica del ilusionismo y de la brujeria, al divertimento popular precinematográfico, como la proyección de sombras chinas, la linterna mágica, el panorama, todos esos dispositivos ilusionistas que exigian una sala oscura y que, consecuentemente, evocaban la caverna de Platón" 3 .

Asi se enfrenta la aparente dicotomia entre la imagen y la palabra, en relación a la imagen conceptual que representa esta última y que nació al alero de las artes visuales: "Si es verdad que la imagen está en el origen de toda escritura ( $y$, en ese sentido, la escritura verbal no es sino una forma altamente especializada de iconografia), también es cierto que la imagen nunca dejó de ser una cierta modalidad de escritura, es decir un discurso construido a partir de un proceso de codificación de conceptos plásticos o gráficos. El arte, tantas veces simplificado por sus detractores y acusado equivocadamente de imitar lo real, en verdad siempre fue una forma de "escribir" el mundo" 4 .

Para Burke, aunque no de modo estricto, "las imágenes son la mejor guia para entender el poder que tenian las representaciones visuales en la vida política y religiosa de las culturas pretéritas" 5 . Una de las posibilidades de comprobación de esta facultad es la expresión fotográfica, las fotografias que toma determinado individuo pueden ser consideradas como discursos icónicos producidos por sujetos que además de ser individuos, son cuerpos investidos por relaciones de poder. "Esto es, que las fotografias no son atribuibles únicamente a un manejo individual o a una apropiación especial de la cámara, sino a una serie de disposiciones que se traducen en saberes y competencias de la cámara" 6 a través de las cuales su ejecutante actúa como etnógrafo develando aspectos a veces ocultos de la sociedad que registra.

Siguiendo el planteamiento anterior, Burke establece que el valor documental de las imágenes y la manera en que nos acercarnos a la "verdad" que éstas ofrecen del pasado es una cuestión esencial, insuficientemente abordada por la historiografia tradicional a través del estudio de grabados pinturas, dibujos y fotografias o el cine, generalmente integrados como auxiliares, con el propósito de enriquecer objetivamente un documento "oficial". El autor señala que imágenes no deben ser considerados reflejos objetivos de un tiempo y espacio sino parte del contexto social que las produjo, y es cometido del historiador reconocer este contexto e integrar la imagen en ét.

Existiria una especie de "invisibilidad de lo visual", entre los historiadores o los especialistas del arte, los que a menudo "prefieren ocuparse de textos y de hechos políticos o económicos, y no de los niveles más profundos de la experiencia que las imágenes se encargan de sondear"; asociado a una "actitud de superioridad para con las imágenes" que esto presupone" ${ }^{\text {"7 }}$.

La situación precedente pierde consistencia si atendemos la postura de Marc Bloch al expresar "que "el stock de documentos" del que dispone la historia no es limitado; aconseja no utilizar exclusivamente documentos escritos y recurrir a otros materiales (...) Las imágenes pintadas o esculpidas, la đisposición de las tumbas y su mobiliario pueden documentarnos sobre sus creencias y actitudes por lo menos tanto como muchos escritos" $"$.

Las imágenes pocas veces forman parte del acervo documental del historiador puesto que generalmente son apéndice a la labor escrita, en las ilustraciones los comentarios son menores y rara vez contienen un análisis que no prescinda del texto, por lo tanto, desde el punto de vista de la construcción del conocimiento histórico, han sido considerados de un escaso aporte al planteamiento de nuevas problemáticas.

\footnotetext{
Machado. Arlindo. 2002 "El cuarto iconoclasmo.... p. 54.

(1)id, p. 58 .

3 Burke, Peter 2001. Visto y no visto, , p. 17.

- Corona Berkin, Sarah. 2000. "Un andisis cultural de la fotografia", Dialogos de la Comrunicación, Revista Latinoanericana de Facultaides de Comunicación Social, 57, p 58.

Burke, P. 2001 . Visto y no visto.... . p. 12

1. Citado por Bourdé y Martin, 1992. Las Escuelas Históricas, Madrid. Akal, p. 156.
}

Revista de Historia, año 18, vols. 18-19, 2008-2009, pp. 163-179. 
La exploración del lenguaje icónico es reveladora para el caso de la prehistoria, en que la imagen se convierte en el único testimonio existente de prácticas sociales tales como la caza, como en el caso de los testimonios rupestres de Altamira y Lascaux. Lo mismo puede afirmarse para algunos estudios a partir del mensaje de tapices en la Edad Media, como El Tapiz de Boyeaux o la interpretación sobre las pinturas de las catacumbas en Roma que fueron estudiadas en el siglo XVIII como testimonio de cristianismo primitivo?

Especialistas en historia de la cultura como Jacob Burkhardt (1818-1897) y Johan Huizinga (18721945) basaron sus descripciones e interpretaciones de la cultura de Italia y de los Paises Bajos en las pinturas de artistas tales como Rafael o van Eyck, asi como en textos de la época. Burkhardt se referia a las imágenes en términos de monumentos, o "testimonios de las fases pretéritas del desarrollo del espiritu humano", de objetos "a través de los cuales podemos leer las estructuras de pensamientos y representación de determinada época" 10 .

Burke concibe el film como un relato visual "... las peliculas son iconotextos que muestran mensajes grabados para ayudar al espectador o influir en él a la hora de interpretar las imágenes. Entre esos iconotextos uno de los más importantes es el título de la película, que influye en las expectativas del público antes incluso de contemplar una sola imagen"11!

La imagen-acción nos remite a un signo, a través de una anécdota nos percatamos del mensaje implicito en la obra y captamos la intencionalidad del realizador. En este punto parece pertinente transcribir integro el comentario que Villalba y Sepúlveda realizan sobre un ejemplo, un clásico del cine argumental:

En "El acorazado Potemkin" (de S.E. Einsenstein, 1925) encontramos una voluntad permanente por hacer trascender el signo al nivel del símbolo, de elaborar la imagen más allá de la equivalencia anecdótica y elevarla a un nivel de interpretaciones que superan el aspecto funcional de la acción. Esta intención es previa al montaje mismo, el cual valorizará indudablemente el elemento portante de acción. El grupo de marineros que duermen, al comienzo del film, en los preliminares al motin, no significa solamente marineros durmiendo: es todo el pueblo ruso en los albores de la revolución. Los anteojos del médico-oficial son anteojos y al mismo tiempo signo de cultura de una clase que juzga lo que debe comer un pueblo según una cierta estructura de poder. Esos anteojos que, doblados en dos se convierten en una especie de microscopio, y captarán los gusanos que comerán, con la carne, los tripulantes del "Potemkin" (alimento del pueblo ruso) lo veremos después - en un juego de imágenes - en la escena del amotinamiento, balanceándose en un rincón del barco, descifrando la acción anecdótica: el médico ha caído (y con ello la cultura y la ciencia al servicio de la clase dominante), sin que el espectador haya visto la caida del médico directamente ${ }^{12}$.

\section{EL DOCUMENTAL DE RECONSTITUCIÓN HISTÓRICA}

La historiografia actual presenta tres sectores particularmente desarrollados: la historia estética del filme, la historia económica del fenómeno cinematográfico... y, más recientemente, su historia sociocultural... La primera predomina y dispone de "modelos" preexistentes, los de la historia del arte y de la literatura que ha debido de adaptar. La segunda se desarrolla dentro de la esfera de influencia de la economía general y parece independiente de la precedente sin que pueda substraerse a determinaciones tecnológicas o sociológicas. Por último, la historia sociocultural se enmarca dentro del vasto campo de la historia social y confrontada a todo tipo de metodologias más o menos claramente conceptualizadas en el marco de la historia de las representaciones, de las mentalidades, de los fenómenos culturales ${ }^{13}$.

Las peliculas de valor histórico o sociológico son filmes que, sin una voluntad directa de hacer Historia, poseen un contenido social y, con el tiempo, pueden convertirse en testimonios importantes de la Historia, o para conocer las mentalidades de cierta sociedad en una época determinada, tal es el caso de películas que se inscriben en el neorrealismo italiano, como Vittorio De Sica con El Ladrón de Bicicletas o los films de la Escuela Soviética como La Huelga de Einsenstein, entre otras.

Ferro las denomina de reconstrucción histórica, pues son filmes que retratan a la gente de una época, su modo de vivir, sentir, comportarse, de vestir e incluso de hablar. Que son sin pretenderlo, testimonios de

\footnotetext{
Burke, P. 2001, Visto y no visto.,., P. 13

10 toud.

11 toid, p. 202

12 Villalba L., y Sepulveda, E. 1988-89. "E Cine", Aistheris, Pontificia Universidad Catolica de Chile, 13, p. 90.

in Lagny, Michele; Cine e historia probiemas y método.
} 
la Historia, que requieren la atención del historiador: investigador y pedagogo ${ }^{14}$. Estas se identifican como cine histórico y sobre las cuales el historiador advierte situarse critico puesto que, al menos en sus premisas, este cine no es más que el punto cero del análisis histórico.

Para Burke su valor radica en que "... gracias a la localización del escenario en una aldea o sus inmediaciones, la película realiza una gran aportación a la "microhistoria", término habitual entre los historiadores a partir de los anios setenta, pero usado ya en los sesenta por el especialista en historia del cine y critico de peliculas Siegfried Kracauer"

Los filmes de intencionalidad histórica son aquellos que, con una voluntad directa de hacer Historia, evocan un periodo o hecho histórico, reconstituyéndolo con más o menos rigor, dentro de la visión subjetiva de cada realizador, de sus autores. Se trata pues de un trabajo artístico-creativo que está más próximo a la operación historiográfica moderna que al libro de divulgación.

Para Ferro estos filmes son de reconstitución histórica, obras fundamentales como fuentes de investigación histórica y como medio didáctico. Pero que precisan de un análisis riguroso para ver en qué sirven como nueva reescritura de la ciencia histórica. A veces nos dicen más de cómo pensaban o piensa los hombres y mujeres de una generación y la sociedad de una determinada época sobre un hecho histórico pretérito que del mismo hecho histórico en sí. En este caso el director cinematográfico se convierte en historiador $\mathrm{y}$ el historiador en una especie de director secundario ${ }^{16}$.

Precisaremos otra categoria del cine documental en que se inscribe la propuesta de análisis que se desarrolla en el capitulo final de este escrito. Se trata del documental de divulgación histórica, la caracteristica principal de este género es estar dirigido a un público masivo al que se le presentan los acontecimientos de un modo distinto del convencional, alejado de tecnicismos académicos.

Según Reyes existen dos formas de validación del conocimiento, una enfrentada a los sujetos expertos, que necesitan de una demostración empirica de los fenómenos, otra dirigida al público masivo, no especializado para la que se requiere otra forma de presentación fundamentada en la persuasión y en el lenguaje retórico.

De este modo el documental de divulgación histórica apunta hacia la emocionalidad del espectador. Esta emocionalidad, a fin de reforzar la retórica y la narración, se logra mediante la utilización de una serie de recursos técnicos (planos, encuadres, yuxtaposición, sonido, etc.) que permiten crear tensión, suspenso o cualquier otra sensación.

La presentación dramática de los acontecimientos es una caracteristica de este género que Rosenstone y Kuelh destacan: "Los espectadores a los que se dirige el documental de divulgación histórica no forma una audiencia "cautiva" (...) para conseguir mantener la atención del espectador, configura un relato de hechos pretéritos de forma dramática es decir mediante la apertura, el desarrollo y el cierre de un conflicto. Además... este conflicto está normalmente protagonizado por un conjunto de personas que han realizado actos heroicos o admirables o que han sufrido la explotación y opresión en un grado extremo"17.

En términos de Nichols, este documental corresponderia a la modalidad expresiva: "Los textos expositivos toman forma en torno a un comentario dirigido hacia el espectador, las imágenes sirven como ilustración o contrapunto (...) La retórica de la argumentación del comentarista desempeña la fusión dominante textual, haciendo que el texto avance al servicio de su necesidad de persuasión"18.

En este contexto es necesario hacer la distinción entre la mirada del documentalista y la del historiador. El primero es un experto en cine, la téenica cinematográfica es su experticia, aún cuando pretende acercarse a la verdad histórica, requiere la asesoria de especialistas en Historia. En otras cuestiones de indole metodológica como el abordaje de los testimonios y los testigos, la diferencia estriba en la subjetividad del documentalista, en torno a este tema Ferro señala "Los documentalistas limitan nuestro conocimiento, en diferentes grados, reduciéndolo al suyo propio, ya que en el documental está presente la subjetividad, la predilección del documentalista, por aquellos actores sociales que puedan, a su juicio, representarse ante la cámara con mayor expresividad (...) si al eineasta le parece que carecen de esta potencialidad, rara vez los va convertir en el núcleo central del documental" 19

\footnotetext{
if Caparrós, I. M 1997. TEl cine como documento históricos un nuevo método de investigación, conocimiento y aprendizaie de la realidad sociocultural", en Anthropos, Huellas Del Conocimiento, Revista del contro de investigaciones film-historie, Barcelona, Proyecto A Ediciones, p. 43 ,

15 Burke P. 2001. Visto y no vista.,. p. 211.

i6 Caparnós, I. M. 1997. El cine como documento histórico..., p. 44.

17. Rosenstone, Robert. 1997. El pasado en imaigenes, El desafio del cime a muestra idea de La historia, Barcelona, Ariel. p. 22.

14 Nichols, Bill 1997. La representación de la realidad. cuestiones y conceptos sabre d docamental, Barcelona, Ediciones Paidos, p. 68

18 Ferro, Marc. 1995. Historia contempondiriea y cine, Barcelona. Aricl, p. 17.

Revista de Historia, año 18, vols. 18-19, 2008-2009, pp. 163-179.
} 
El documental de divulgación histórica se ocupa de temas socialmente relevantes que involucran a toda la sociedad y que afectan los imaginarios colectivos a través de, utilizando la categoría de Ferro, la reconstitución de procesos históricos que contribuyen a reforzar la identidad cultural.

Esta clasificación se enmarca claramente dentro del conjunto de peliculas en que los realizadores, por cierto comprometidos ideológicamente, evocan el pasado con el fin de "hacer historia"; en el mismo sentido que los filmes de reconstitución histórica, en que el interés se centra en lo que los distintos actores pueden aportar de su percepción o experiencia en un acontecimiento del pasado o del presente por sobre la recreación de determinado periodo histórico. Como afirma Pelaz López, se utilizan en el sentido clásico de historia como "maestra de la vida"20.

Constatamos que además del ingrediente subjetivo, característico del género documental, la dimensión emotiva y testimonial, es otra de sus particularidades, que se da a menudo en la relación documentalista- testigo, al reconstruir un hecho, la prevención es observar cuidadosamente las versiones que pueden estar manipuladas o mediadas por la amnesia. No obstante desde el punto de vista testimonial el documento resulta terriblemente auténtico.

Esta autenticidad de la explicación histórica implicita en el documental contribuye a sondear los "silencios y omisiones" de la historia, como señala Ferro. El documental es un planteamiento y a la vez una mirada a la que subyace una ideologia, una cultura; esa perspectiva, muchas veces interdisciplinaria, nos muestra un panorama global de la realidad social. Al preservar la memoria colectiva, el documentalista es responsable, tanto como el historiador de re-testimoniar su historia y de re-escribir La Historia.

\section{PREVENCIONES PARA EL ANÁLISIS}

Prescindiendo de otro tipo de relaciones que se puedan establecer entre el critico y el film, como parámetros de códigos socioculturales preestablecidos, el estudioso de la historia se plantea frente a la obra cinematográfica "como si fuese un objeto único, ciertamente relacionado con el reto del arte, la historia (social y del cine) pero que, por ser una realidad en si, con un lenguaje propio, se manifiesta de diversas maneras, cuantas sean las obras que existan ( $\mathrm{y}$ estaremos frente a una critica fenomenológica). Por último, puede poner la atención en el artista y tratar de comprender el mensaje que quiso plasmar en su obra (enfrentándonos, entonces, a un análisis de contenido, basado, fundamentalmente en las técnicas de la lingüistica) ${ }^{21}$

Estos son algunos de los flancos por los que atacar la crítica del film documental. Tratando de desentrañar el mensaje que subyace a la obra y su estrecha vinculación con el panorama sociopolitico de la época que registra desde un análisis de forma y contenido.

En este marco entenderemos el film como "un discurso significante, un objeto percibido por un espectador durante una cantidad determinada de tiempo, una obra que se constituye en fenómeno multidimensional $y$, que, por lo mismo, es susceptible a diversas lecturas y diversos análisis. Y este film (a través del cual en forma directa o indirecta llegamos al fenómeno general del cine) el objeto especifico de estudio para el crítico" 22 , en nuestro caso el historiador.

Como fenómeno multidimensional, el film es aprehensible desde diversos ámbitos. Es posible analizarlo a partir de varias lecturas: desde una perspectiva sociológica como un objeto de consumo, o sea un bien social, por cjemplo, las repercusiones de cierta obra sobre las conductas sociales; en la misma perspectiva, susceptible realizar un análisis de contenido en torno a los aspectos internos de la obra con repercusión en las masas. Desde la perspectiva estética, se pueden estudiar aspectos como la música o las imágenes, que dan carácter a la obra significada. Desde la ciencia de la conducta, el análisis psicológico de los personajes, que es la más clásica.

Una aproximación histórica puede provenir de dos fuentes: "o del análisis histórico del tiempo interior del relato (por ejemplo, en "El huevo de la serpiente" de Bergman, corresponderia un análisis del contexto histórico de la Alemania Federal prenazi de los años 20), o de los condicionamientos históricos del director, en relación a su biografía tomada como su pertenencia a un tiempo y un espacio determinados, su filmografia, su inserción en la historia del cine, su pertenencia a escuelas o movimientos cinematográficos, si

\footnotetext{
20 Pelaz Loper, fosé Vidal. 2006. "El pasado como espectaculo: reflexiones sobre la relación entre la Histotia y el cine"; LEGETE Estudios de Comunicación y Sociedad, Universidad Católica de la Santisima Concepción, Escuela de Periodismo, N=7, p. 130.

21 Meza, M*Eugenia, "Apuntes para una reflexión sobre la critica del cine", Aisthesis, Pontificia Universidad Catolica de Chile, Santiagor p. 74.

12 Ibid., p. 75 .
} 
sus trabajos están realizados en forma marginal a una industria y, en caso contrario a cuál pertenece, etc., 23 .

A propósito de la figura del realizador, Carr advierte en su obra 2Qué es la Historia?: "Estudiad al historiador antes de empezar a estudiar los hechos", al parangonar la frase entendemos que es aconsejable que: "... todo el que intente utilizar el testimonio de una imagen, que empiece por estudiar el objetivo que con ella persiguiera su autor" 24 .

Sobre la critica al cine como ocurre frente a cualquier otro tipo de fuente histórica, asegura Rolle: "debe plantear el por qué y cómo se ha dejado dicho registro filmico, cuál era la intencionalidad del realizador, con qué medios actuó al llevar a cabo dicho registro, si fue un acto independiente o bien contratado, si fue programado o espontáneo o si las imágenes presentadas fueron montadas siguiendo un guión -un discurso narrativo establecido a posteriori en muchos casos- o bien se trata de la presentación de un conjunto de imágenes que busca ser un reflejo de la vida simplemente" 25 .

Covengamos en que toda "operación histórica" al rescate de lo testimonial que se propone el documentalista (o el historiador), se contempla "el trabajo de la critica a través de la selección de imágenes, la generación de secuencias y el uso de recursos sensoriales como la utilización de música o sonido, lo que se sintetiza en el proceso de montaje de un filme. También el documentalista se interroga sobre la relación enigmática que sostiene con la sociedad presente y con la muerte gracias a la mediación de unas actividades técnicas" 26 .

\section{UNA METODOLOGIA DEL TRATAMIENTO DE LAS IMÁGENES}

La utilización de las imágenes como testimonio plantea no menores problemas desde el punto de vista metodológico. Las imágenes transmiten determinado mensaje que como prevención, y al contrario de lo que sucede con los testimonios escritos, el historiador debe intentar "leer entre líneas", evitando caer en el error de interpretar lo que el artista no sabia que estaba diciendo. Esto porque la "critica de las fuentes" es distinta que en la documentación escrita. La crítica de los testimonios visuales por estar muy poco desarrollada sugiere, como en ocasiones con el testimonio escrito, "problemas de contexto, de función, de retórica, de calidad del recuerdo (si data de poco o muchos después del acontecimiento) si se trata de un testimonio secundario, etc. Por eso algunas imágenes ofrecen un testimonio más fiable que otras"27.

En este contexto es responsabilidad del historiador intentar dar respuesta a la cuestión sobre hasta qué punto y de qué forma ofrecen las imágenes un testimonio fiable del pasado y esto va a depender de diversos factores contextuales a la obra y lo que se pueda desentrañar a partir de un análisis exhaustivo.

Independiente a su calidad estética, las imágenes son potenciales documentos, pues son reflejo de la cultura que las originó y actúan como agentes de la historia. Burke señala "cualquier imagen puede servir como testimonio histórico. Los mapas, las planchas decorativas, los exvotos, las muñecas de moda o los soldados de cerámica enterrados en las tumbas de los primeros emperadores chinos, cada uno de estos objetos tiene algo que decir al historiador" 28

En relación a los filmes, existe esta capacidad de documentar la realidad social. "Un destacado autor de películas etnográficas, Robert Gardner, afirmaba que el cine ofrece un testimonio "de un tipo directo y carente por completo de ambigüedades, por cuanto capta la realidad de manera instantánea, sin que sufra las distorsiones debidas a errores de percepción visual, de memoria o de interpretación semántica ${ }^{-\cdots} 29$. Es el caso de las peliculas de corte antropológico, en las que con mayor nitidez se presenta esta particularidad.

Reconocer el cine como documento, con su valor testimonial implicito (y explicito), esboza de paso una problemática metodológica "el problema radica en evaluar esta modalidad de testimonio, en desarrollar un tipo de critica de las fuentes que tenga en cuenta las caracteristicas del medio, del lenguaje de la imagen en movimiento. Como ocurre con otros tipos de documentación, el historiador debe enfrentarse al problema de la autenticidad" ${ }^{30}$. Con otros matices comparte el cine esta cuestión con los documentos escritos.

2) Ibid., p. 76

14 Burke, Peter. 2001. Visto y no visto..., p. 22.

75. Vega, Alicia. 2006, Itinerario del cime documental chileno, Santiago, Ediciones Universidad Alberto Hurtado, p. 23

26 1bid., p. 23

27. Burke, Peter, 2001, Visto y ne visto....p. 18.

28 Burke, Peter 2001. Visto y no vista..... . 20.

29. Ibid $\mathrm{p} 19 \mathrm{?}$.

so pald.

Revista de Historia, atio 18, vols, 18-19, 2008-2009, pp. 163-179. 
Le Goff ofrece una alternativa, al otorgar al documento filmico la categoria de monumento, es decir, asignarle un valor en si mismo, en la conservación en el imaginario social de lo histórico que comporta, y sentencia "sólo el análisis del documento en cuanto monumento permite a la memoria colectiva recuperarlo y al historiador usarlo cientificamente, es decir con pleno conocimiento de causa" 31 . No sólo como fuente sino como manifestación de interpretación histórica susceptible de ser contrastado con otros medios y lenguajes.

La monumentalidad del documental, radica como señalamos, en su valor testimonial de ciertas realidades consideradas en su contingencia relevantes, al darse a la labor de recoger testimonios de un presente que en prospectiva construirán el futuro, como afirma Rolle "El material generado por las urgencias e intereses de un lugar y un momento se resignifica cuando se trabaja para proponer la trama interpretativa del acontecer humano en el tiempo" 32

Prosiguiendo la ruta del análisis del film, es pertinente detenerse y observar la advertencia que al respecto realiza Aumont, en términos que "no se deberia considerar el análisis de films como una verdadera disciplina, sino, según los casos (...) como aplicación, desarrollo e invención de teorias y disciplinas. Es decir; no sólo no existe una teoria unificada del cine, sino tampoco ningún método universal de análisis de films"33.

Coinciden Casetti y di Chio con el planteamiento de Aumont en el sentido que no existe un modelo general el análisis de una pelicula, en su obra Cómo Analizar un Film ${ }^{34}$ abordan el film como texto, del que se puede desprender un análisis de los códigos del film, de la narración, como de las estrategias comunicativas presentes en las películas, ofreciendo así un cuadro metodológico explicito y general, sinerético, aunque, expresan en ningún caso una receta, puesto que cada critico o historiador diseñará su propia propuesta en base a la necesidad de interpretación que lo motive.

\section{Análisis del documental "Allende, la caída de un Presidente" (2003)}

\section{PRESENTACIÓN}

El documental de corte periodistico, con tintes de reportaje, que la Compañia de Ramos Generales (Argentina) editó con motivo de la conmemoración de los treinta años del término abrupto del gobierno de la Unidad Popular en Chile. Facturado en formato DVD, en Chile por M \& M, en este film, dividido en cinco capitulos, aplica una perspectiva sintética acerca de los inicios del gobierno de Salvador Allende hasta la instalación de una nueva etapa sociohistórica en Chile con el Golpe Militar de 1973.

En el primer capitulo "Salvador Allende. La caída de un presidente" se aborda la llegada al poder del presidente socialista, las dificultades en su asunción, la adhesión de las masas, la oposición de la derecha, el rol de los Estados Unidos y de las Fuerzas Armadas en la decadencia y fin del régimen.

Las últimas horas de Allende en el Palacio de la Moneda se encuentran en las imágenes montadas en "11 de septiembre. El Golpe: hora por hora", que da nombre al segundo capitulo.

En "Pinochet. Retrato de una dictadura", el tercer capitulo, se recogen antecedentes personales, profesionales e ideológicos de Augusto Pinochet como de las caracteristicas del régimen instalado con la Junta de Gobierno en 1973 y culmina con la llegada después de su detención en Inglaterra, luego que el juez Baltasar Garzón dictara orden de captura y extradición, cuando fue declarado incapaz por su edad y estado de salud.

El cuarto capítulo aborda "Allende y Cámpora. Encuentro de dos presidentes", el viaje realizado por Allende a Argentina con motivo de la ceremonia de asunción de Héctor Cámpora como presidente de la República Argentina. Las adhesiones de los militantes peronistas y algunas declaraciones de los protagonistas.

Un apartado especial merece el quinto capítulo "Pablo Neruda. La muerte de un poeta", en que se trata la amistad y camaradería entre Allende y el Nóbel.

Para efectos de nuestra propuesta metodológica, centraremos nuestro análisis en el capítulo I

\section{"Salvador Allende. La caida de un presidente".}

En la producción ejecutiva se encuentra Román Lejtman (...), en la producción general Evangelina Diaz. La realización a cargo de Pablo Garcia, sobre el guión de Carolina González. La producción de imágenes bajo Carola Fernández Moores y la locución en off de Eduardo Ferrari. La edición on-line por

\footnotetext{
") Citado en Vega, Alicia. 2006. Itinerurio del cine.... p. 28.

32 Ibid, p. 28.

3) Aumont, Jacques. 1988. Analisis del film, Bancelona, Paidós, p. 13.

4. Casetti. Fy di Chio, F. 1991 , Cime analiear un film, Barcelona, Ediciones Patdós.
} 
Magdalena Mosquera y Damiản Cereijo, mientras que el diseño y arte electrónico por Mario Arias. La música original corresponde a Carlos Gramuglia, La investigación periodistica estuvo en manos de Evangelina Diaz. y Silvina Kaspin, las entrevistas fueron realizadas por Cecilia Jimènez y Silvina Kaspin. La cámara de Jorge Garcia. Producción y autoria del dvd de Enrique Londaits y el diseño gráfico por cuenta de Olivy.com.ar

La Compañia de Ramos Generaies es una productora de programas periodísticos de televisión abierta y de cable- $\mathrm{y}$ de documentales históricos que se han realizado para importantes medios de comunicación. Esta empresa periodistica editó documentales para los canales A/EMundo, Infinito y Canal á, y para los medios gráficos argentinos Página/12 y Revista Noticias. Esta Compañia está dirigida por Román Lejtman, uno de los periodistas más reconocidos en la Argentina.

Las imágenes fueron extraidas de otros documentales, entre los que se distingue "La Batalla de Chile", de Patricio Guzmán y de noticieros de la televisión chilena de la época como también otras inéditas en Chile acerca de Salvador Allende y su gobierno.

La calidad del documental en tanto fuente para la historia radica, más allá de su atractiva presentación (estética del film) y de su postura ideológica, en la mirada que realizadores de otra nacionalidad dirigen a un proceso histórico que aún está abierto a múltiples interpretaciones. Esto evidencia que se trata de hechos que trascienden el escenario nacional y se convierten en situaciones de interés mundial. Es reconocido que la via chilena al socialismo fue una coyuntura sui generis que aún concita adhesiones o rechazos dentro de ciertos círculos politicos e intelectuales y que además se ha instalado en imaginario colectivo de la comunidad internacional.

\section{PROPUESTA DE ANÁLISIS SEGÚN EL MODELO DE MARC FERRO}

Como se ha expuesto en el apartado anterior existen diversas propuestas metodológicas para abordar el análisis del documental y en especial del documental de reconstitución histórica (Ferro) o también llamado de divulgación histórica (Rosenstone). En nuestro estudio de caso hemos optado por la metodologia del pionero en establecer las relaciones historia-cine, el maestro francés Marc Ferro, quien en su obra Cine e Historia ofrece una propuesta de critica del documento filmico, como critica del film de montaje, argumental y documental, cuyos pasos fundamentales resumimos a continuación:

"El análisis de un film de montaje requiere dos operaciones distintas:

- el estudio y la crítica de los documentos que se utilizan en el film;

- la critica de su puesta en marcha; ésta se inicia con la realización del film que no es necesariamente contemporánea de los documentos utilizados"35

Consideraciones previas: pertinencia de la metodologia y el estudio de los tipos de documentos utilizados en el film:

Ferro advierte que esta propuesta puede ser no pertinente cuando:

- en las escenas algunos planos rodados por el mismo autor al momento de realizarse la película y las alterna con planos de archivo. También cuando utiliza elementos técnicos para acentuar algunos aspectos, por cjemplo, a iluminación.

- el realizador entrevista a testigos de los acontecimientos y estos no corresponden realmente a las imágenes (se sale del contexto temporal de la imagen).

En el "film de montaje" los autores buscan preferentemente, documentos no montados, $o$ en su defecto temas de noticiarios para los que asimismo disponen recortes, es decir, secciones del documento no montadas; o bien buscan documentos que ya se han rodado pero que jamás hayan pasado por un montaje, documentos que recién la mención de no utilizados (N.U.) $)^{36}$.

Además de los tipos de documentos filmicos descritos existen otra serie de secciones compuestas de elementos de origen no cinematográfico, tales como:

- Fotografias, dibujos animados, etc.

- Secciones ya montadas, en las que no entran ni recortes ni N.U.

- Secciones montadas a partir de los N.U.

\footnotetext{
35 Ferro, Marc, Cime e historta, Barcelona. Editorial Giustavo Gilfi, 5.A., p 92.

16. tbid, p. 93

Revista de Historia, ano 18, vols. 18-19, 2008-2009, pp. 163-179.
} 
- Secciones de origen no cinematográfico.

El conglomerado de tales secciones, que se incrementan con escenas rodadas, con extractos de peliculas đe fieción, entrevistas, etc., constituye el montaje propio del film llamado "de montaje"37

A. La critica de los documentos que se utilizan en el film:

Ferro afirma: "Podemos abordar la critica histórica y social de los documentos de cine a partir de varios puntos de vista, $y$ sobre todo reproducir los métodos empleados para fuentes de diversa indole" 38 .

Se examina este análisis bajo tres aspectos: la critica de autenticidad, la critica de identificación y sobre todo la critica de análisis:

- La crítica de autenticidad: en que se trata de verificar sobre el estudio de diversos atributos el tipo de documento y de esta manera constatar si ha sido objeto de reconstitución o adulteración.

- La crítica de identificación; la forma más familiar y más fácil entre historiadores y otros cuentistas sociales. Supone buscar el origen del documento, fecharlo, identificar sus personajes y lugares, interpretar el contenido, etc.

- La critica de análisis: a través de esa se determina y estudia la fuente emisora, las condiciones de la producción, la función del documento, su frecuencia (documentos ủnico o repetitivo) su recepción de parte de los espectadores eventuales, etc.

A. La critica de su puesta en marcha; análisis de la realización:

La realización "... lleva consigo una ideologia, conciente o no. Por eso hacet la crítica de un film de montaje requiere a la vez el recurso al procedimiento que se aplica a una tarea no cinematográfica y el recurso a un procedimiento diferente, especifico de la escritura cinematográfica" ${ }^{39}$, esto se manifiesta en la selección y conjunción de las imágenes, así como a naturaleza y función de los comentarios, eventual utilización de entrevistas, la sonorización, entre otros elementos que constituyen el documental u otro film de montaje.

Nos parece pertinente incluir en forma textual los comentarios sobre el documental que se destacan en voz en off, de modo de hacernos una idea de como se desarrolla el filme (en Anexo).

\section{ANÁLISIS DEL DOCUMENTAL.}

Desde el punto de vista de los documentos filmicos, Allende, la Caida de un Presidente, está compuesto por secciones montadas gracias a recortes recuperados y probablemente por secciones montadas a partir de imágenes no utilizadas y otras de origen no cinematográfico.

\section{A. Análisis de documentos}

a) Crítica de autenticidad: un análisis del montaje nos evidencia la autenticidad de las imágenes incluidas a partir de ciertos atributos como:

La duración de los planos: estos planos son numerosos y de corta duración, con cortes, aunque insertos ritmicamente, con la música y voz en off a lo largo de todo el documental. Los cortes van directamente relacionados con antiguos archivos incorporados de tal manera de dar sentido de tiempo real, lo que aporta indicios de reconstitución de imágenes. La mayor parte está relacionada con actos multitudinarios ocurridos sucesivamente en un mismo periodo. Otros con la figura discursos o entrevistas a Allende y otras figuras destacadas en el periodo.

La angulación de cámara: al tratarse de imágenes recortadas de archivo de prensa y archivos personales, se aprecia que son representaciones cinematográficas, en el mayor de los casos, poco sutiles y de escaso tratamiento técnico, rescatando más las acciones que se producen, que la intención de los planos. En gran parte de la cinta se utilizan ángulos normales; para resaltar las acciones o discursos de los protagonistas se recurre al ángulo picado y contrapicado. Los ángulos cenital y nadir, escasos, y aberrante, no observado. Se utiliza también los punto de vista subjetivo y objetivo, reconocibles en el contexto de la secuencia que integran.

12. Foid.

16 roid. p. 94.

* Ibia, p. 93 . p. 126 . 
La iluminación: en general, a to largo del documental se demuestra el aprovechamiento de la luz natural, ya que se exhiben las grandes multitudes, de dia y de noche, siendo las tomas, en general, en blanco y negro. Los planos no están perfectamente encuadrados y la iluminación no es uniforme en el desarrollo del filme lo que denota sus cualidades de montaje o reconstitución.

El grado de intensidad de la acción de la película: la originalidad de este documental, que aborda la contingencia sociopolítica de un periodo, es que sigue el guión con cierta progresión dramàtica, siguiendo la linea de tiempo de sucesos, partiendo por hechos de identificación para llegar a hechos de máxima intensidad. Las secuencias son unidades que mantienen la intensidad de la acción en todo momento. Es un montaje de tiempos fuertes.

\section{b) Critica de identificaciỏn}

"Allende, la Caida de un Presidente" es un documentał que está montado a partir de diversas imágenes de archivos de prensa y de otros realizadores que captaron los sucesos en su desarrollo. Reconstituye el periodo de la Unidad Popular en Chile (1970-1973) enfatizando en la figura de Salvador Allende. Los lugares y personajes en general corresponden a los hechos narrados, no obstante se identifiquen algunos silencios, errores u omisiones históricas.

\section{c) Crítica de análisis}

La Fuente emisora: la Compañia de Ramos Generales, a cargo de Román Lejtman, es una productora independiente que ha abordado varios hechos históricos en formato documental. La factura del film de reconstitución denota una clara intencionalidad de parte de su realizador y seguido muy de cerca por su productor ejecutivo Lejtman, al realizar una especie de apologia al gobierno del socialista Allende. La prođucción se realizó en 2003, con fecha de la conmemoración de los treinta años de la caida de la Unidad Popular.

Condiciones de la producción: sobre estas existen escasos antecedentes. Desde que se inició la investigación se ha intentado establecer contacto con el realizador infructuosamente. No obstante se logró comunicación electrónica con la productora general, Evangelina Diaz, quien no aportó mayores datos, aludiendo solo a que ya no trabajaban con el director. Al demandar más información se ha recibido de su parte un curriculo de Lejtman, en el que aparecen un sinnúmero de rcalizaciones documentales producidas bajo su auspicio, entre otras se mencionan la guerra de Los Balcanes y el atentado a la AMIA. Se señala en el documento "Todos estos documentales fueron realizados con material histórico inédito de nuestros propios archivos". Sin embargo, no hay alusión alguna a "Salvador Allende. La Caida de un Presidente" tal como lo distribuyó la empresa importadora en Chile. Una búsqueda por la Web permitió descubrir que el documental circuló en Argentina bajo el nombre de "Santiago Ensangrentada" con la dirección del mismo Lejtman.

En este marco se puede afirmar lo que es posible extraer de la información de carátula como del currículo de Lejtman. Se ha determinado que el documental es de producción privada. Estableciendo que las condiciones para su realización fueron óptimas en consideración de la factura técnica del material filmográfico, que se filmó en conmemoración de los 30 años de la caida de la Unidad Popular y que contó con material histórico inédito, al menos en nuestro pais.

Ahora bien, en el rótulo del DVD original que circula en Chile aparece una indicación sobre la factura del este formato en territorio nacional por M\&M producciones S.A., sin encontrarse datos de esta empresa.

La función del documento: el documental centra su interés en rescatar imágenes de la memoria colectiva de Chile en tiempos de la Unidad Popular, a partir de una serie de fuentes contemporáneas. Se pueden distinguir claramente imágenes que pertenecen a la televisión o a la obra de Guzmán "La batalla de Chile" y otros del período o anteriores, en un contexto de cine militante. Se pone de manifiesto la inteneión de destacar la figura política de Salvador Allende, intercalando continuamente sus alocuciones, Por lo tanto, la función principal del documento es narrar los hitos del proceso de implantación del proyecto socialista en Chile, resaltando a su mentor el médico Salvador Allende, a propósito de la conmemoración de los 30 años de su muerte y del gobierno que encabezó.

El análisis de planos: éstos son variados, al ser insertos de poca duración pero a la vez precisos y concretos, se utilizan planos generales para mostrar la magnificación y popularidad que Allende concitaba en Chile de entonces. 
Predominan los planos generales que presentan un escenario amplio en el que se distingue el mundo popular y se capta el ambiente de participación social. Situa muy bien al personaje principal, Allende, sobre todo en ocasión de la proclamación de sus discursos.

El plano entero es un recurso escaso en esta producción. Los planos medios que muestran a personas especificas, del mismo modo; en relación a los movimientos, de cámara son recurrentes travelling. acompañados de paneos y tilt, mostrando a las masas en movilizaciones.

El primer plano es característico en Salvador Allende en alocuciones y entrevistas.

\section{B. ANÁLISIS DE LA REALIZACIÓN}

El montaje: es dinámico, coincidiendo con planos cortos, en armonia con la música y la voz en off, Se otorga un sentido informativo ya que son imágenes de la época, evidentemente reconstituidas. Trasformando la noticia en un documento a través de recursos técnicos como secuencias intercaladas y comentarios. Se trata de un montaje repetitivo en el que se repiten las siguientes situaciones:

- Planos generales de manifestaciones en masa, de adherentes y detractores al gobierno.

- Planos medios y primeros planos de las alocuciones del protagonista de la narración, Salvador Allende.

- Planos que recrean la carrera política de Allende.

- Planos referentes a las condiciones impuestas por el sistema económico de la época.

- Planos cortos con testimonios de los involucrados en aquella época.

- Entre otros.

Se observan una "cortinas" introductorias con diversos matices de colores entre los que destacan el rojo y el negro, con efectos multimediales, de fondo la figura de Allende y otras situaciones hito que el director pretende resaltar.

Los comentarios: o la voz en off en este documental son un referente importantisimo. Existe un alto grado de relación entre el texto y los plano-secuencia, no obstante de detecten errores u omisiones. Una trascripción total de los comentarios se encuentra en el Anexo de este trabajo. Se indican al respecto algunos elementos discursivos de interés:

En el texto, para efectos de formalidad, se han colocado en color rojo todas aquellas expresiones que indican presencia de rasgos discursos del hablante, y aquellas secciones que están subrayadas dan muestras de aquella evidencia, pero aun más, denotan rasgos de una postura política afin al sujeto del documental. Es decir, de Salvador Allende y su gobierno.

En la primera cita leemos:

Pero el candidato socialista, debió recorrer un camino lleno de obstáculos hasta llegar al poder, en el entorno politico mundial y chileno, algumos verán con mala cara la llegada de Salvador Allende al Palacio de la Moneda, sede del Gobierno chileno.

Este párrafo da cuenta en forma explicita de la simpatia del narrador hacia Salvador Allende. Los marcadores como "Pero", la expresión "debió recorrer un camino lleno de obstáculos hasta llegar al poder", nos dan cuenta de que el triunfo y poder no fue tarea fácil para el recién nominado Presidente de Chile.

La oración: "algunos verán con mala cara la llegada..." es una muestra evidente de la postura del narrador. Ya nos anticipa la presencia de grandes obstáculos en lo que será el gobierno, y que deja en claro que este triunfo para él es un gran triunfo, pero a otros, identificados posteriormente con los grandes conglomerados económicos, de poder y mediales de Chile, harán gala de su conexiones con Estados Unidos - tesis propuesta por el narrador- durante todo el discurso, y que se convertirán en aquellos enemigos acérrimos de Allende y, en consecuencia, en este relato son puestos en evidencia desde el principio como una forma de mostrar los verdaderos enemigos.

En otro momento, cuando la crisis gubernamental es evidente, el emisor nos da la siguiente señal: Allende les daba batalla a sus adversarios

Aquí el emisor nuevamente se plantea en forma directa con sus destinatarios de forma tal que ya, una vez construida con las expresiones como la analizada anteriormente, va construyendo una imagen de Allende como un luchador de sus ideales y que él, en tanto narrador, acoge al dar cuenta que no será făcil combatir el 
Gobierno de Allende, que en todas las instancias llega legítimamente al Gobicrno. Usa para ello los términos batalla y adversarios, vocabulario que nos lleva semánticamente al campo de la guerra, y nuevamente, con estos recursos, da cuenta quienes serán aquellos que harán la guerra al gobierno: la derecha oligárquica en conjunto con las Fuerzas Armadas, haciendo las salvedades propias que la historia de Chile acusa.

En virtud de lo anterior, la oración más evidente de un colapso está dada como un guión de cíne y documental que precipita la acción de los participantes de esta gran pugna política:

La noche del 10 de Septiembre los conspiradores uttimaron todos los detalles.

Los conspiradores ya están reconocidos, sólo faltan que salgan a realizar su último acto, el ataque a la casa de Gobierno de Chile; La Moneda. Evidentemente, ya aqui lo que parecía un relato objetivo a ido convirtiéndose en un relato donde narrador y emisor se identifican con el objeto del documental, Allende. La postura es abiertamente afin a la de él. discurso:

Cierra con oraciones que marcan su postura politica y llevan al receptor a identificarse con su

La historia chilena quedaba marcada por sangre y fuego.

Con la muerte de Allende mucha sangre seguiria corriendo en los dias siguientes al Golpe. un despliegue represivo cubrió a Chile.

Ambas oraciones despliegan narrativamente el enmarque que indica dónde quiere finalmente el narrador encontrarnos, que logremos tal como él lo hace, la misma lectura histórica y política que el ha hecho durante todo el proceso.

El discurso no sólo es de carácter politico, con los marcadores que se usan para avanzar progresivamente para ello, sino que además hay una postura tal que se desea llevar al receptor a leer argumentativamente la misma óptica del documentalista, y para ello todos los recursos fueron usados de esa forms.

Los sonidos: los sonidos ambiente están representados por las grandes movilizaciones de personas que participan en mítines políticos, asimismo se escucha en versión original el contexto y las alocuciones de Allende, entrevistas y opiniones de diversos actores sociales de la época. Por ejemplo, las comunicaciones radiofónicas entre miembros del Ejército en momentos en que se bombardeaba La Moneda o, en el mismo contexto, el ruido de los aviones o del bombardeo a la Casa de Gobierno, entre otras secuencias significativas.

La música: a lo largo de todo el metraje se oye una música monotónica de alto impacto auditivo que da la impresión de intensidad, en algunas secuencias que se introducen en las "cortinas", son sonidos rítmicos en forma de eco, que dan un aspecto de tensión, de dramatismo y en algunas ocasiones de terror, respetando los silencios.

Los silencios: son escasos si no inexistentes, el sonido y la música ocupan cada espacio guiando al espectador hacia la narración y de alguna manera predisponiéndole a los hechos a través de su impacto. Se deduce que este recurso busca claramente mantener la atención del espectador dejando poco espacio a la reflexión, una caracteristica de este género documental.

A partir de la aplicación del método de Ferro, con algunos matices otorgados por el investigador al documental de reconstitución histórica "Allende. La Caida de un Presidente" es posible constatar:

\section{Evaluación histórico-critica}

Este documental recoge una serie de fuentes homónimas que se nutren de la prolifera creación de filmes de este género, de carácter militante, que se produjeron durante la Unidad Popular. Entre ellos, apreciamos La Batalla de Chile, de Patricio Guzmán, archivos de prensa y de la televisión nacional e imágenes inéditas en Chile de la visita de Allende a Argentina y otras, que fueron montadas a efectos de conformar una obra con notorios ingredientes de reportaje, reconstituyendo la historia enmarcándose en la clasificación de divulgación histórica.

Aunque se carece de mayores antecedentes del realizador, aunque sí de la empresa que lo produjo, es posible distinguir la intencionalidad y los componentes de subjetividad y persuasión propios de este género. Se deduce que existe un claro interés por resaltar la figura politica y personal de Salvador Allende y del gobierno de la Unidad Popular, desde una perspectiva biográfica y hasta apologética. El objetivo, sin lugar a 
dudas, es convencer al espectador y conducirlo hacia la construcción de una imagen favorable de este personaje histórico.

La obra está dirigida al público general, ya que la presentación en forma de reportaje, conforme a la estructura periodistica capta la atención del espectador, los recursos utilizados conforme a la clasificación de filme de divulgación histórica, escapa al academicismo y se dirige al público común en un lenguaje llano y convierte la pelicula en un texto filmico fácil de leer.

Esta cinta destaca de sus precedentes más conocidos, como la obra de Guzmán y Henriquez, en que nutriéndose de los mismos documentos los integra de forma atractiva, haciendo uso de la herramienta informática multimedia se convierte en un texto dinámico, incorporando secuencias y tomas inéditas.

El documental contextualiza el periodo internacional de la Guerra Fría en el cual Allende desarrolla su coartado mandato, haciendo referencia al temor que significaba para los Estados Unidos que asumiera el lider socialista. Esta pelicula aporta datos desconocidos, como la visita de Allende a Argentina, que sirven a la reconstrucción de periodo junto a la historiografia.

Desde el punto de vista técnico las imágenes exhibidas son reconstituciones de un periodo y una contingencia sociopolitica que se logra recortando diversas secuencias y planos sobre el gobierno de la Unidad Popular: de los discursos de Salvador Allende durante su campaña y como presidente, de las manifestaciones populares de los principales actores sociales de entonces. Predominan planos generales y primeros planos, en secuencias breves, en ocasiones las filmaciones denotan escasa producción y escasa nitidez, ya que se aprovecha la luz natural, sea de noche o de día, que para el tipo de pelicula de la época y el predominio del blanco y negro afectan la presentación. Hay un compromiso por enfocar y captar la instantanea. Otras tomas que corresponden a entrevistas a Salvador Allende en ambientes internos y con detalles de enfoque e iluminación que dan cuenta de una producción. El juego de imágenes recurrentes es otro recurso de persuasión. La narración es continua, con una voz en off entonada y enfática, acompaña todo el desarrollo del la película.

Se utilizan cortinas con efectos que impresionan al espectador y apela a la emotividad mostrando imágenes de Allende combinado con los emblemas patrios, de personas detenidas y otros recursos similares. Las imágenes recurrentes corresponden a los detenidos luego del golpe de Estado, del bombardeo a La Moneda y de la figura de Allende en diferentes situaciones.

En análisis de las secuencias permite detectar algunos errores desde la perspectiva de la narración filmica sobre algunos hechos tratados que no encuentran correlato con la imagen exhibida. En varias ocasiones se narra un episodio de la Unidad Popular y se exhiben imágenes que no corresponden a ese período.

Desde el punto de vista del montaje, para la recreación del martes 11 de septiembre de 1973 se utilizan imágenes de los años anteriores del gobierno de Allende desde 1970 a 1972 . Sobre esta misma secuencia se hace mención a los aviones que bombardearon La Moneda, pero no se indica de dónde despegaron, siendo desde la provincia de Concepción, es una omisión.

Otra imagen que se inserta continuamente a lo largo del documental es la presencia de Allende con su esposa Hortensia Bussi saludando a la ciudadania desde uno de los balcones de La Moneda, celebrando el triunfo en la elecciones de 1970. El director recurre a esta fórmula para enfatizar distintos mensajes.

A la vez son notorios los plano secuencia de Salvador Allende en su interacción con la gente, en las calles, en las poblaciones, con los trabajadores y colaboradores.

El pueblo que caracteriza esta cinta es una ciudadania que sale a las calles, que participa en las campañas politicas, que marcha y se moviliza. Se traspasa la idea de multitudes comprometidas con los cambios sociales que se llevan a cabo y participes de las medidas del gobierno. En estas aglomeraciones se refleja el mundo popular, los trabajadores, las mujeres; todos, todos a quicnes apelaba el discurso politico de Allende.

Se hacen algunas alusiones a ciertas contingencias politicas, por citar un ejemplo, de la referencia de la voz en off a la participación de Salvador Allende en la fundación del partido socialista que va acompañado de escenas de personajes que por sus ademanes representan un grupo de oposición. Por otro lado, pancartas que señalan Matte, hacen presumir que hay una relación al movimiento militar que daria origen a la República Socialista.

Los grupos de la derecha, la burguesía o los terratenientes son representados siempre en oposición al gobiemo, aunque su aparición es menor en relación a personeros o colectivos simpatizantes al gobierno. Su participación en el relato sirve para graficar el clima de descontento interno, cuando se manifiestan contrarios 
al comunismo y lo expresan con pancartas, consignas o declaraciones. En el caso de las manifestaciones se les presenta se enfrentados a la fuerza pública, a propósito de las políticas de nacionalización implantadas por Salvador Allende.

La figura de Salvador Allende se vincula a las multitudes, a las aclamaciones del pueblo y se construye como un progresista de izquierda. Su discurso de Allende se elabora desde la toma de conciencia histórica. Se reitera la idea que él junto al pueblo son los promotores de cambios revolucionarios en un margen democrático, en libertad, excluyendo de este proyecto a los antidemócratas y a los fascistas.

Como parlamentario o como presidente electo o en ejercicio, en las entrevistas se declara antimperialista, marxista de origen, siempre firme en sus palabras, con gran capacidad de oratoria.

Durante su campaña defiende la opción de velar por los altos intereses nacionales y que el suyo seria un gobierno del pueblo, asentado en la idea de engrandecer al pais y fortalecer la patria.

Cuando saluda a los invitados a su llegada al gobierno en alocución del Estadio Nacional el 05 de noviembre de 1970 denota una conciencia histórica de la responsabilidad que significa transitar por la via chilena al socialismo.

Está conciente que la derecha va creando una situación de inestabilidad interna. Califica de planes sediciosos los pasos de los poderes fácticos y de alguna manera anticipa que su gobierno será dificil y que se podrian desencadenar situaciones dolorosas para el pais (en alusión al atentado de Schneider).

Allende genera una revolución con los trabajadores, conciente de la importancia de la economía en el logro revolucionario de los recursos naturales y la riqueza del pais.

Se mantiene en margen de respeto con Nixon y su gobierno, advirtiendo el respeto también por la autodeterminación de los pueblos y la no intervención, dispuesto a enfrentar cualquier agresión en nombre propio y del pueblo. En defensa de las relaciones diplomáticas, culturales y comerciales con las demás naciones y la libertad de establecer relaciones con quien quiere tener (Cuba).

La derecha aliada al imperialismo en su intento de impedir el acceso del pueblo al gobierno. Su discurso ante la ONU es bastante claro y frontal respeto de lo que estaba sucediendo en ese momento en el pais (1972). Ante la intervención de la CIA y el clima de boicot interno del empresariado nacional, insta al apoyo de su gobierno y a la responsabilidad del pueblo.

Se muestra a Allende persona, Allende padre y esposo, con referencias a varias escenas familiares, en que lo acompaña su hija Beatriz o en su hogar.

Son importantes las intervenciones de varios protagonistas del periodo como el General Prats, quien en una entrevista reconoce la connotación politica del atentado al General Schneider. También es interesante la presentación del saludo protocolar de Frei Montalba a Salvador Allende, que más bien tiene un carácter de camaradería y apoyo como ambos declaran. Asimismo la visita de Fidel Castro a Chile, sus declaraciones en ef Estadio Nacional en noviembre de 1971, cuando expresa que la experiencia chilena es insólita y reconoce que es la primera en su tipo en la historia de la humanidad.

Las representaciones del general Pinochet, lo muestran como un militar firme y resuelto, que descubre sus propósitos hacia el final del relato. Sus intervenciones en diálogo con el General Palacios el dia del Golpe y luego en sus comunicados ya conformada la Junta de Gobierno son una fuente que ilustra bien su rol en el término del gobierno de la Unidad Popular.

Se intercalan varias escenas que no corresponden a la época narrada o son anteriores o constituyen proyecciones del realizador y se adelantan a los hechos. Por citar un caso, en referencia a la Democracia Cristiana en el contexto de la campaña de 1970 (Tomic) se menciona Eduardo Frei Montalba y se muestran imágenes de cuándo asume su mandato.

Otro recurso que se ocupa bastante es el apoyo de la prensa escrita, de los titulares, como los del diario El Mercurio, a propósito del atentado que costó la vida al General René Schneider, entre otros.

Otra forma de enfatizar es resaltar en colores los documentos escritos como el documento desclasificado del Proyecto FULBELT, sobre uno de ellos se nota tarjada la fecha original 16 por 17. Lo mismo ocurre para TRACK I y TRACK II.

Para ilustrar el contexto de la Guerra Fría se recurre a imágenes de Nixon, misiles dólares, La Casa Blanca, la transnacional ITT, entre otras.

Una de las inconsistencias o errores a propósito de la mención de la nacionalización del cobre, es utilizar imágenes de faenas mineras que se desarrollan en el norte del pais pero que claramente son anteriores y que podemos situar a comienzos del siglo XX, por la calidad de la filmación, la rapidez de las acciones de 
adolescentes y niños saliendo de lo que parece ser una faena de explotación, la indumentaria como la maquinaria es rudimentaria y no corresponde al desarrollo tecnológico alcanzado en el Chile de la década de los setenta.

Otra situación en que es notoria la superposición de la voz de Allende en referencia a los efectos del movimiento militar del 29 de junio de 1973, no existe coincidencia entre el discurso del presidente y las imágenes que pueden corresponder a una situación anterior en que se dirige al país. Desde ef punto de vista del contenido, en esta alocución reconoce la labor de las fuerzas leales al gobierno.

A lo largo de toda la cinta se grafica la posibilidad de una intervención militar con imágenes de la conformación de la Junta de Gobierno de 1973.

Se reconstituye en forma apreciable el clima de incertidumbre desde el triunfo de Allende hasta su ratificación por el Congreso Pleno.

De la misma manera se ilustra de forma ejemplar la situación de confrontación social y la polarización politica, como ocurre con la "marcha de las cacerolas", episodio en que se rescata el testimonio de dos mujeres, una adherente y otra detractora al gobierno, desde el punto de vista discursivo resulta muy revelador de la concepción que tenia un grupo sobre el otro.

Otra secuencia rescatable es la presentación de la crisis de desabastecimiento, el paro del transporte. empresarios, representados por León Villarin y sus expresas declaraciones, los trabajadores del transporte, los trabajadores voluntarios del gobierno que hacen de fiscalizadores en definitiva el ambiente de las colas para obtener los productos o el mercado negro, entre otras situaciones como la protesta del 06 de noviembre.

El Tanquetazo del 29 de junio de 1973 se exhibe acertadamente, siendo imágenes conocidas y que se utilizan, aunque fuera de contexto, para llenar algunos vacios en el episodio del martes 11 de septiembre de 1973.

La imagen emblemática de La Moneda en llamas que ha recorrido el mundo, con la bandera presidencial flameando mientras los aviones rasantes van destruyendo la Casa de Gobierno. Reflejan muy bien los interiores y el contexto de la situacion.

Las intercalaciones de reportes de prensa nacional que nutren la narración y contribuyen a construir un relato claro y panorámico.

El último discurso de Salvador Allende por Radio Magallanes y la significatividad de su mensaje, otra secuencia que es un aporte,

En relación al texto, que corresponde a la voz en off, por ejemplo, se lee que el partido Radical era un partido de Izquierda, en tanto puede ser calificado de centro izquierda. Se alude a grupos separados de la Democracia Cristina, sin especificar, siendo éstos primeramente el MAPU (1969) y posteriormente la Izquierda Cristiana (1971), conglomerados que formaron parte de la Unidad Popular. O en el subtitulo incorrecto, como el caso de Enriquez Froden, que aparece como Enrique Espinoza (su hijo).

La asunción de Allende es calificada como el inicio de una escalada comunista que EEUU debia detener, no obstante este hecho constituye la continuación de aquello, pues situándolo en contexto latinoamericano habria que considerar como antecedente la Revolución Cubana (1959) que especialmente Nixon y su Secretario de Estado, Kissinger, no estaban dispuestos a aceptar.

La voz en off cae en una nueva omisión cuando señala que desde 1970 los programas de ayuda económica por parte de los EEUU disminuyeron. Sin embargo no hay mención a que lo único que no disminuyó fue la asistencia militar, que por el contrario, aumentó.

Cuando se presenta el viaje, entre otros paises, de Allende a la URSS, se expone que esta potencia de la Guerra Fria apoyó económicamente a Chile, aunque, se omite, esta ayuda no cumplió con las expectativas del primer mandatario socialista y es más en la misma órbita soviética hubo ciertas aprehensiones frente a la experiencia socialista chilena.

Se menciona que hacia fines de 1972 se esboza una crisis politica, momento en el cual algunos empresarios opositores e integrantes de las FFAA, estrechan lazos en vista del un golpe de Estado. En la actualidad es una situación cuya existencia no se cuestiona.

Hacia el final de la cinta, respecto de la causa de muerte del presidente Allende se relata que éste se suicidó de un tiro en la cabeza, en consecuencia que, según algunas versiones, se disparó en el mentón, lo cual provocó el destrozo de la cara y parte del cráneo.

Se hace alusión a que hubo colaboradores que acompañaron a Allende el día del golpe pero no se indica quienes fueron esas personas. Está claro que entre éstas se cuentan algunos detectives, su secretaria 
privada y sus médicos personales. Tampoco se menciona cómo evacuaron La Moneda.

Entre los desafios se encuentra realizar un análisis del discurso y de la construcción de los distintos actores sociales y sujetos históricos que exhibe el film y la consistencia de la narración, considerando, como ya se ha mencionado, la imagen como texto. Puede ser un buen complemento de las fuentes escritas o es susceptible de cotejar con otras fuentes o documentos de la misma naturaleza audiovisual, no obstante se enfatice en el valor de la imagen por si sola como soporte comunicante.

A la luz de la critica por parte del analista especializado es posible detectar algunas omisiones, errores o aciertos en relación a la construcción de la verdad histórica en la interpretación de la pieza fílmica.

Puede leerse que el director presenta una visión parcializada de la crisis sociopolitica que afectó al gobierno de la Unidad Popular. En la narración, de una u otra forma, se responsabiliza directamente a los Estados Unidos, a los empresarios chilenos y a los partidos de oposición. Una omisión flagrante es la no referencia a la crisis interna experimentada por la coalición gobiernista.

\section{A MODO DE CONCLUSIÓN}

Es posible realizar un análisis de los filmes desde una perspectiva histórica, interiorizándose en los nuevos métodos de abordaje de las fuentes audiovisuales. Una prevención necesaria al embarcarse en esta nueva empresa para el neófito, es considerar que el cine es un fenómeno de carácter multicausal y por lo tanto susceptible de diversas lecturas y análisis. Una de las metodologias más aceptadas por los especialistas, ya superados los análisis semiológicos que ofrecia el estructuralismo, son las aproximaciones de carácter socio histórico.

Como cualquier otro documento con que se enfrenta el historiador, el filme implica una labor de critica externa y critica interna, procedimientos que se adaptan a las particularidades de este formato. Independiente de los pasos a seguir, es importante que el historiador o cualquier otro profesional de las humanidades y de las ciencias sociales, sea capaz de concebir y comprender el filme como una imagendocumento, como un iconotexto, que es factible leer e interpretar y que contribuya a la re-escritura de la Historia.

El historiador francés Mare Ferro ${ }^{40}$, maestro de las relaciones historia-cine propone una metodología interesante que consiste en plantearse una critica del documento filmico y la crítica de la realización, que correspondería a los momentos de la crítica externa e interna del documento escrito. A partir de éste se puede llegar al establecimiento de análisis globales, que incorporen estudios sobre las categorias discursivas, por ejemplo, lo que escapa la pretensión de este trabajo. No obstante esta forma de evaluación histórico critica del filme, nos ha permitido establecer el grado de utilidad de este documental para la historia de Chile contemporáneo, en términos de cuestionar los silencios, omisiones y aciertos de la pelicula.

El especialista es representante de su cultura, en este sentido traslada la dimensión subjetiva a su obra, que dice relación con su situación dentro de la sociedad como sujeto histórico y como actor social que realiza una labor de reconstitución del pasado, en este punto es donde encuentra similitudes con el método del historiador, quien recompone aspectos de cuando ese pasado fue presente.

Escapando a todo presentismo, es oportuno señalar que la historia se interpreta desde la contemporaneidad y rescata aquella contemporaneidad de la época sobre la cual se realiza el análisis. El documentalista recupera imágenes instantáneas captadas en el momento oportuno con una intencionalidad. El cine actua entonces como catalizador de los hechos, como agente de la historia.

Pierre Sorlin 41 afirma que las peliculas muestran el anverso de la historia, Mientras Mare Ferro 42 declara que la imagen en movimiento cumple con un objetivo que va más allá de lo esperado y de lo puramente cinematográfico, que es revelar to no contemplado, to involuntario, aquello que sobrepasa la "realidad representada" o lo que es lo mismo facilitan un "contraanálisis" de la sociedad. Para Sorlin esto supone que el historiador debe demostrar maestria en la confrontación de los filmes con otros medios de expresión.

La obra analizada desafia la Historia, impone una metodologia distinta de la que se acostumbra en la crítica de documentos escritos, que implica el acercamiento a ciertos elementos teóricos y técnicos con los

\footnotetext{
40. firid.

1) Sorlin, P. 1997 . Socjologì del cone. La apertura para la historia de mañana, Méxica, FCE.

42 Ferro, Marc 1995. Historia contemponanea y cine.

Revista de Historia, año 18, vols. 18-19, 2008-2009, pp. 163-179.
} 
cuales el historiador tradicional no está familiarizado, más que por falta dé interés o de actualización, por la falta de orientaciones en la lectura de la imagen.

Constituye un desafio también por la posibilidad que ofrece de transformar la historia, la que se narra en el filme o hasta la que ya está escrita. En este caso "Allende, la Caída de un Presidente", plantea reflexiones y cuestionamientos que dicen relación con la autoria y con el contenido de la obra.

Este documental puede ser clasificado como cine de la memoria o cine de autor, que a su vez está montado en base a otras piezas documentales que se inscriben en un estilo, una línea ideológica y un contexto determinado cual es el cine social y militante de la década de los setenta. Subjetividad y persuasión, son elementos básicos que a partir de diversos recursos técnicos el realizador se traspasa al espectador desde un componente emotivo en las secuencias y en la narración que acompaña las imágenes. Es una cinta de divulgación histórica.

El filme de reconstitución histórica en esencia se construye y se lee como un texto escrito, se presenta como un guión, que se estructura como una crónica de la realidad, del período de la Unidad Popular. La operación histórica del montaje es similar a la escritura (tradicional) de la Historia,

El documental que analizado es un iconotexto potente. Se trata de un filme de reconstitución histórica, según Marc Ferro y a la vez puede ser catalogado como un documental de divulgación histórica, en la clasificación de Robert Rosenstone, desde el punto de vista metodológico ofrece otras posibilidades: cotejarlo directamente con fuentes escritas o entre otros filmes que reconstituyen el periodo de la Unidad Popular a partir de un análisis sociohistórico de su contenido. 